Biotechnology

\section{Troubled company back in credit}

Gaithersburg, Maryland

BETHESDA Research Laboratories Inc. (BRL), the prominent US biotechnology firm that hit trouble a year ago after growing rapidly since it was set up in 1976 , is thinking of making a public stock offering. M. James Barrett, the former Smith-Kline Beckman executive who was made BRL's president as part of the rescue operation, says that the company now has enough "real value" to go public some time in the next year.

BRL's renewed interest in offering shares for public sale may be influenced by the very strong recent market in biotechnology stocks (Nature 10 February, p.459). The strong market may also have caused another biotechnology-based company, the Swiss Biogen NV to apply to the Securities and Exchange Commission to make a public offering. Centocor, a smaller firm in Malvern, Pennsylvania, went public in December.

Some Wall Street analysts are sceptical as to whether BRL has changed from its high-flying days which nearly led to bankruptcy (Nature 296, 3; 1982). Only the eleventh hour intervention of venture capitalist Frederick R. Adler saved the company. Adler arranged emergency financing, almost exactly a year ago, on the condition that he be given complete control as chairman of the BRL board's executive committee.

In the reorganization, the president Stephen C. Turner, who founded the company was made chairman of the board. Turner and Adler recruited James Barrett

\section{New blood flows in}

THE University Grants Committee is this week sifting through more than 1,000 applications for the $\mathbf{2 0 0}$ new university posts at British universities made available under the scheme for recruiting "new blood" in science, engineering and medicine. Although the closing date for applications was passed last Friday, applications were still flowing in earlier this week.

Altogether, there are 300 new posts available, 30 in the humanities and the social sciences while $\mathbf{7 0}$ are earmarked for specialists in information technology, more than half of whom will be employed in running training courses of various kinds. The present plan is that applications for the $\mathbf{2 0 0}$ places in science, engineering and medicine will adjudicated by the end of March by the grants committee and the research councils, when successful universities will be allowed to advertise their vacancies.

The scale of application appears to have varied dramatically, with some universities applying for only a handful of new posts and other asking for close on a hundred. from Smith-Kline Beckman. Barrett's reasons for believing BRL to be healthy once again shed light on the inner workings of the many biotechnology firms springing up in the United States.

BRL was founded by Turner in 1976 to capitalize on the new need for enzymes and reagents among researchers in the thennew field of genetic engineering. BRL's sales grew, along with its reputation as a principal supplier of materials and instrumentation for genetic engineering research. In 1977 sales stood at $\$ 350,000$. In 1980 they stood at \$5 million.

The phenomenal growth, just when biotechnology was becoming fashionable in the financial world, encouraged BRL to look to further expansion by raising funds by a public stock offering. This caused it to diversify into 11 different "hot" areas.

Fundamentally, the research and development programme was designed so that the prospectus (the booklet of promises a company issues when it offers stock for public sale) would show "page after page of enormous technology potential residing at BRL", Barrett says. With this approach, the company raised $\$ 16$ million in private stock offerings over two years.

But the market for BRL's products could not support such rapid expansion and at one point BRL had only $\$ 800,000$ per month coming in from sales and was market was in the doldrums in early 1982 , so hopes that the company could suddenly acquire cash from the long-sought public stock offering faded. By early 1982 , some $\$ 9$ million in back debt had accumulated. The crisis broke and Adler stepped in.

BRL's retrenchment cost hundreds of employees their jobs (the firm now employs 214 , down from a peak of around 450 ), the breaking of a contract to buy a large building and the quick sale of Glenco, a company acquired to take BRL into the field of chromatography.

Barrett laid off more people and cut out activities not central to BRL's core business, so as to get a positive cash flow. Although Adler raised $\$ 9$ million to pay off back debts, BRL did not have a positive cash flow until last November.

Ironically, BRL was saved in part by the growth of the rest of the biotechnology field: despite all its problems, sales in 1982 reached $\$ 13$ million - $\$ 3$ million more than in 1981 . The projects cut were programmes in instrumentation development, cell biology and the use of growth factors in therapy. BRL had a lot of work in diagnostics but has stopped all but some long-term research in cancer and viral diagnostics.

Barrett sees BRL as remaining a principal supplier to the research community, but branching into a few carefully selected "end user" areas.

Deborah Shapley spending \$2 million per month. The stock
Information technology Prospect of more

research money ing towards acceptance of the chief recommendations of the Alvey report on information technology, published last autumn. In a report to the Department of Industry, a committee under Mr J. Alvey, a director of the telecommunications monopoly British Telecom, urged a five-year programme of research and development costing $£ 350$ million, three-quarters of the cost to be met by the government and the rest from industrial sources.

Mr Kenneth Baker, the minister at the department with special responsibility for information technology, told the House of Commons last week that he would "soon" be able to announce the government's response. The proposals have not yet been considered by the cabinet, which is likely to be especially concerned with two features of the proposals - that three-quarters of the total cost should be met from public funds, and that the programme should be managed by a special directorate set up within the Department of Industry.

Meanwhile, funds to support some parts of the programme appear already to have been allocated. Last year's earmarking by the Advisory Board for the Research Councils for the support of information technology is indeed more than that recommended by Alvey, at least in 1983-84, but in future years the Science and Engineering Research Council will have to divert funds from elsewhere in its budget if the Alvey target is to be met. Similarly, the Department of Industry's research and development budget for the coming year has been increased by $£ 60$ million to $£ 218$ million, more than the cost of meeting the obligations spelled out by Alvey even after allowing for inflation.

The Alvey report seems to have won the hearts and minds of British ministers by its emphasis on the need to strengthen basic technology in Britain. The intention is to concentrate on four areas of research - software engineering, very large scale integration of circuits, what is called the man-machine interface and "intelligent knowledge-based systems". The report also includes a specific timetable suggesting when particular goals in each of the four chosen fields should be attainable.

One of the most remarkable features of the report is that its authors were able to promise on behalf of the British Ministry of Defence that military interests in the development of information technology would be coordinated under the same umbrella, although projects related to particular defence needs would continue separately. There are few precedents for this apparent readiness to acknowledge that defence needs are not unique. 